\section{Regeneration of Ornamental Cherry (Prunus) Taxa from Mature Stored Seed}

\author{
Karen E. Hokanson ${ }^{1}$ and Margaret R. Pooler ${ }^{2}$ \\ U.S. Department of Agriculture, Agricultural Research Service, U.S. National \\ Arboretum, Floral and Nursery Plants Research Unit, 3501 New York Avenue \\ NE, Washington, DC 20002
}

\begin{abstract}
Additional index words. organogenesis, growth regulators, cotyledon, hypocotyl, Prunus campanulata, P. maackii, P. sargentii, P. serrula, P. serrulata, P. subhirtella, $P$. virginiana, $P$. yedoensis
\end{abstract}

\begin{abstract}
Callus formation and adventitious shoot regeneration in vitro from mature stored seed were evaluated in eight ornamental cherry (Prunus) taxa: $P$. campanulata Maxim., $P$. maackii Rupr., $P$. sargentii Rehd., $P$. serrula Franch., $P$. serrulata Lindl., $P$. subhirtella Miq., $P$. virginiana $L$., and $P$. yedoensis Matsum. Several portions of the embryo (cotyledons and hypocotyl sections) and nine combinations of growth regulators $(B A, 2,4-$ D, IBA, NAA, and TDZ) were compared. Effects of embryo portions and growth regulator treatments were generally small within taxa, but shoot formation differed among taxa. About $20 \%$ to $50 \%$ of the embryos from $P$. virginiana and $P$. serrula and $\approx 5 \%$ to $30 \%$ of those from $P$. maackii produced shoots. The other taxa generally did not produce shoots. Regeneration from mature stored seed in the responsive taxa represents a potential system for genetic transformation. Chemical names used: 6-benzyladenine (BA); 2,4-dichlorophenoxyacetic acid (2,4-D); indole-3-butyric acid (IBA); $\alpha$-naphthaleneacetic acid (NAA); thidiazuron (TDZ).
\end{abstract}

As genetic transformation of plants becomes more common, the opportunity to move otherwise unavailable traits into germplasm for breeding and cultivar development increases. A number of improvements have been made to ornamental plant material via genetic transformation (Robinson and Firoozabady, 1993; Schuerman and Dandekar, 1993; Zuker et al., 1998). In general, transformation is less successful in woody ornamentals than in herbaceous plants, due in large part to the fact that woody plants are more difficult to regenerate (Birch, 1997; Capellades Queralt et al., 1991; Geneve et al., 1997; McCown, 1986; Read and Hosier, 1986).

Quarantine restrictions have made importation of new ornamental cherry (Prunus) germplasm into the United States for breeding increasingly difficult; hence, genetic engineering may be necessary to introduce genes that confer resistance to insects and disease, as well as genes for ornamental traits such as

\begin{abstract}
Received for publication 22 Mar. 1999. Accepted for publication 1 Sept. 1999. Mention of a trademark, proprietary product, or vendor does not constitute a guarantee or warranty of the product by the U.S. Dept. of Agriculture and does not imply its approval to the exclusion of other products or vendors that may also be suitable. We thank Ralph Scorza, Dick Zimmerman, and Tom Zimmerman for valuable comments on the manuscript; Dave Liewehr for statistical assistance; and Rob Griesbach and Ron Beck for technical assistance and borrowed space. The cost of publishing this paper was defrayed in part by the payment of page charges. Under postal regulations, this paper therefore must be hereby marked advertisement solely to indicate this fact. ${ }^{1}$ Current address: U.S. Dept. of Agriculture, Animal and Plant Health Inspection Service, Scientific Services, Riverdale, MD 20794.

${ }^{2}$ To whom reprint requests should be addressed; e-
\end{abstract} mail address: mpooler@ars-grin.gov growth habit. Popular flowering cherry cultivars represent a diversity of species (e.g., $P$. serrulata, $P$. sargentii, $P$. subhirtella, and $P$. campanulata) and hybrids (e.g., $P$. campanulata Xincisa Thunb. 'Okame', $P$. yedoensis) of known and unknown origin, which are grown primarily for their floral display, and all of which are clonally propagated. Some lesser-known species, such as $P$. virginiana (fall leaf color), are grown for ornamental traits other than springtime blossoms.

Although a few studies have investigated regeneration potential in ornamental cherry species (da Camara Machado et al., 1995), there are a number of reports of regeneration and transformation among nonornamental Prunus. Immature embryos and somatic cell lines have been used for peach [Prunus persica (L.) Batsch], plum ( $P$. domestica L.), and apricot $(P$. armeniaca L.) regeneration (Hammerschlag et al., 1985; Mante et al., 1989; Pieterse, 1989), but these explant sources depend on precise timing and/or time-consuming procedures. There are also reports of regeneration and transformation from leaf tissue of plum and almond (P. dulcis D.A. Webb) (Bassi and Cossio, 1991; Mehra and Mehra, 1974; Miguel et al., 1996). Leaves from plants established in tissue culture are an excellent source of explants, because they are convenient and allow the manipulation of a specific ported from cotyledons of immature seed of peach, sour cherry (P. cerasus L.), and plum, and from cotyledons of mature stored seed in peach (Mante et al., 1989; Pooler and Scorza, 1995). Virus-resistant transgenic plum plants were regenerated from hypocotyls of mature seeds following Agrobacterium-mediated transformation (Mante et al., 1991; maackii and $P$. serrula (ornamental bark) and $P$. genotype or cultivar. Regeneration is also re-
Ravelonandro et al., 1997). Mature stored seed are also a convenient explant source, although they do not allow a specific genotype to be manipulated.

Few ornamental cherry cultivars are established in in-vitro culture, so leaf material is not readily available for regeneration and subsequent transformation of cultivars. However, regeneration and transformation from mature, stored seed represents a convenient tool to introduce novel genes into the flowering cherry germplasm, and would also be ideal for seedpropagated taxa that are used as rootstocks. Our objective in establishing regeneration and transformation in Prunus seed is to introduce novel genes for disease and pest resistance and ornamental traits into the ornamental cherry germplasm, so that we can use the resulting plants as parental material in our breeding program. To that end, we examined the regeneration potential of mature seeds from eight ornamental cherry taxa, all of which are grown predominantly for their ornamental traits and are readily clonally propagated. We examined the responses of explants from various portions of the mature embryos to combinations of growth regulators.

\section{Materials and Methods}

Seeds from the following eight taxa were included in this study: $P$. campanulata, $P$. virginiana, $P$. serrula, $P$. serrulata, $P$. yedoensis, $P$. maackii, $P$. sargentii, $P$. subhirtella. Seeds of all of these taxa were obtained from Sheffield's Seed Co. (Locke, N.Y.), and a second seed lot of all taxa (except for $P$. campanulata because only one seed lot was available) was obtained from Lawyer Nursery (Plains, Mont.), or F.W. Shumacher Co. (Sandwich, Mass.).

Before removing the endocarp, pits were soaked in $2.1 \% \mathrm{NaOCl}$ (sodium hypochlorite) for $30 \mathrm{~min}$ and rinsed three times with sterile distilled $\mathrm{H}_{2} \mathrm{O}$. Endocarps were removed, seeds were soaked in $70 \%$ ethanol for $1 \mathrm{~min}$, transferred to $0.8 \% \mathrm{NaOCl}$ with $0.01 \%$ Tween-20 for $30 \mathrm{~min}$, and rinsed three times with sterile distilled $\mathrm{H}_{2} \mathrm{O}$. Following disinfestation, seeds were imbibed overnight in sterile distilled $\mathrm{H}_{2} \mathrm{O}$. The seedcoat was removed, the cotyledons were gently separated by applying pressure to the seed and/or gently scraping with a forceps or scalpel, and the embryonic axis was separated from the cotyledons by gentle scraping with the tip of a scalpel.

Expt. 1. Effects of embryo explant type and taxon on regeneration. Callus and shoot formation were compared among five types of embryo explants: whole cotyledons, whole cotyledons with a notch, half cotyledons, half cotyledons with a notch, and hypocotyls. The half cotyledons were prepared by cutting off the distal portion of the cotyledon with a scalpel, and retaining the proximal portion. Cotyledons were notched, as described in Pooler and Scorza (1995), by removing a small slice on either side of the point where the embryonic axis was attached, forming a "V"shaped notch. Hypocotyls were prepared by slicing off the epicotyl and the radicle from the 
embryonic axis with a scalpel. The experiment was replicated four times with one replicate consisting of 40 plates (five embryo treatments for each of eight taxa). Three to 10 explants per plate were placed on the following regeneration medium: Murashige and Skoog (MS) inorganic salts (Sigma Chemical Co., St. Louis), with: $100 \mathrm{mg}$ myoinositol, 0.4 $\mathrm{mg}$ thiamine- $\mathrm{HCl}, 0.4 \mathrm{mg}$ nicotinic acid, and $0.5 \mathrm{mg}$ pyridoxine- $\mathrm{HCl}$ per $\mathrm{L}$, plus $2.5 \%$ sucrose, $0.3 \%$ phytagar, $0.15 \%$ phytagel, $7.5 \mu \mathrm{M}$ TDZ, and $2.5 \mu \mathrm{M}$ IBA. The medium was adjusted to $\mathrm{pH} 6.0$ and autoclaved for $15 \mathrm{~min}$ at $0.92 \mathrm{~kg} \cdot \mathrm{cm}^{-2}$ before pouring into $25 \times 100-\mathrm{mm}$ sterile polystyrene plates. Cotyledons were placed on the medium abaxial side down. The plates were sealed with parafilm and stored in the dark at $23{ }^{\circ} \mathrm{C}$ for 4 weeks, when the percentage of explants forming callus per plate was recorded. Explants were then transferred to the same medium described above, but with $4.4 \mu \mathrm{M}$ BA instead of TDZ and with only 0.5 $\mu$ M IBA. After this transfer, plates were moved to a 16 -h photoperiod under $\approx 50 \mu \mathrm{mol} \cdot \mathrm{m}^{-2} \cdot \mathrm{s}^{-1}$ of fluorescent light. The percentage of explants forming shoots was recorded at eight to 12 weeks. Embryos of P. campanulata produced no callus or shoots, so were not included in the data analysis.

Expt. 2. Effects of growth regulator, taxon, and seed source on regeneration. Nine combinations of the growth regulators BA, 2,4-D, IBA, NAA, and TDZ were added to the basal MS medium, and whole cotyledon explants were evaluated for shoot regeneration in each taxon. The combinations were as follows, with all concentrations in $\mu \mathrm{M}$ : 1) $0.5 \mathrm{IBA}+7.5$ TDZ; 2) 2.5 IBA + 7.5 TDZ; 3) 2.5 IBA + 12.5 TDZ; 4) 2.5 IBA + 7.5 TDZ transferred to 0.5 $\mathrm{IBA}+4.4 \mathrm{BA}$; 5) $2.5 \mathrm{IBA}+12.5 \mathrm{TDZ}$ transferred to $0.5 \mathrm{IBA}+4.4 \mathrm{BA}$; 6) $0.5 \mathrm{IBA}+4.4$ BA; 7) 1.0 2,4-D + 4.4 BA; 8) 1.0 2,4-D + 4.4 BA transferred to $0.5 \mathrm{IBA}+4.4 \mathrm{BA}$; 9) 4.52 ,4$\mathrm{D}+0.5 \mathrm{BA}$ transferred to $0.3 \mathrm{NAA}+2.5 \mathrm{BA}$ and then to $0.5 \mathrm{NAA}+5 \mathrm{BA}$. Transfers to new or fresh medium were made every 4 weeks. One replicate in this experiment consisted of 72 plates (nine growth regulator combinations for each of eight taxa), with five to 10 explants per plate. The experiment was replicated four times, twice each with seeds from two different seed lots (except P. campanulata). Embryos of $P$. campanulata produced no callus or shoots, so were not included in the data analysis. Two replicates of $P$. subhirtella were lost to contamination, and were also not included in the analysis.

Analysis of variance (ANOVA) was performed on the data with the MIXED procedure (SAS Institute, 1997). For the embryo explant experiment, a randomized complete-block design was used with taxon, embryo explant, and their interaction specified as fixed effects, and blocks specified as a random effect. For the growth regulator experiment, a randomized complete-block split-plot design was used. Whole plots were the two seed sources and subplots were combinations of taxa and growth regulators. Seed source, taxon, growth regulator treatment, and their interactions were specified as fixed effects with block and block $x$ seed source as random effects. In both experiments, percentages were weighted by the number of explants per plate. Residuals were examined graphically for homogeneity and normality. When necessary, heterogenous variance of the residuals was addressed by partitioning the variance into groups of similar variance (Akaike, 1974; Littell et al., 1996). Least square means (lsmeans) are reported, with $\mathrm{LSD}_{0.05}$ used to compare lsmeans. Some single degree-of-freedom planned (a priori) comparisons were also performed: hypocotyls vs. cotyledons, whole cotyledons vs. half cotyledons, notched cotyledons vs. unnotched cotyledons, growth regulator combinations 1 through 5 (with TDZ) vs. 6 through 9 (without TDZ), and growth regulator combinations 2 and 3 (on TDZ without transfer to BA) vs. 4 and 5 (transferred from TDZ to BA).

\section{Results}

Expt. 1. Effects of embryo explant type and taxon on regeneration. Taxa differed significantly in percentages of explants forming callus and producing shoots, but there was no significant difference among embryo explants and no interaction between explants and taxon (Tables 1 and 2). Likewise, differences be-

Table 1. ANOVA of data for percentage of Prunus explants that formed callus and shoots in explant and growth regulator treatment experiments.

\begin{tabular}{|c|c|c|c|c|c|c|c|c|}
\hline \multirow[b]{2}{*}{ Source of variation } & \multicolumn{4}{|c|}{$\%$ Callus } & \multicolumn{4}{|c|}{$\%$ Shoots } \\
\hline & df & $\mathrm{F}$ & $P$ & & df & $\mathrm{F}$ & $P$ & \\
\hline \multicolumn{9}{|c|}{ Embryo Explant Experiment } \\
\hline Taxon & 6 & 32.67 & 0.0001 & $* * *$ & 6 & 12.47 & 0.0001 & $* * *$ \\
\hline Explant & 4 & 1.35 & 0.2567 & NS & 4 & 1.00 & 0.4106 & NS \\
\hline Taxon $\times$ explant & 24 & 0.99 & 0.4819 & NS & 24 & 0.28 & 0.9997 & NS \\
\hline \multicolumn{9}{|c|}{ Planned comparisons ${ }^{z}$} \\
\hline Hypocotyl vs. cotyledons & 1 & 3.2 & 0.0765 & NS & 1 & 0.02 & 0.8758 & NS \\
\hline Half cot. vs. whole cot. & 1 & 0.7 & 0.4181 & NS & 1 & 0.17 & 0.6798 & NS \\
\hline Notched vs. unnotched & 1 & 0.2 & 0.6865 & NS & 1 & 2.15 & 0.1465 & NS \\
\hline \multicolumn{9}{|c|}{ Growth regulator experiment } \\
\hline Seed source & 1 & 41.18 & 0.0214 & $*$ & 1 & 1.77 & 0.1869 & NS \\
\hline Taxon & 5 & 120.36 & 0.0001 & $* * *$ & 5 & 35.40 & 0.0001 & $* * *$ \\
\hline Seed source $\times$ taxon & 5 & 23.67 & 0.0001 & $* * *$ & 5 & 3.56 & 0.0054 & $* *$ \\
\hline Treatment (trtmt) & 8 & 0.66 & 0.7226 & NS & 8 & 4.18 & 0.0003 & $* * *$ \\
\hline Seed source $\times \operatorname{trtmt}$ & 8 & 1.23 & 0.2969 & NS & 8 & 1.05 & 0.4043 & NS \\
\hline Taxon $\times$ trtmt & 40 & 0.77 & 0.8097 & NS & 40 & 9.26 & 0.0001 & $* * *$ \\
\hline Seed source $\times \operatorname{taxon} \times \operatorname{trtmt}$ & 40 & 0.85 & 0.6994 & NS & 40 & 2.77 & 0.0001 & $* * *$ \\
\hline \multicolumn{9}{|c|}{ Planned comparisons } \\
\hline $\begin{array}{l}\text { Trtmts } 1-5 \text { vs. Trtmts } 6-9 \\
\text { (TDZ vs. BA) }\end{array}$ & 1 & 1.40 & 0.2403 & NS & 1 & 11.87 & 0.0009 & *** \\
\hline $\begin{array}{l}\text { Trtmts 2, } 3 \text { vs. Trtmts } 4,5 \\
\text { (No transfer vs. transfer) }\end{array}$ & 1 & 0.04 & 0.8467 & NS & 1 & 2.58 & 0.1116 & NS \\
\hline
\end{tabular}

${ }^{2}$ Although the treatment effect was nonsignificant, planned comparisons were still evaluated because the means of grouped treatments can reveal differences when individual means did not.

ss, ****,****Nonsignificant or significant at $P \leq 0.05,0.01$, or 0.001 , respectively.

Table 2. Main effect of taxon on percentages of Prunus embryos that formed callus and shoots in the embryo explant and growth regulator treatment experiments.

\begin{tabular}{lccccc}
\hline & \multicolumn{2}{c}{$\begin{array}{c}\text { Embryo explant } \\
\text { experiment }\end{array}$} & & \multicolumn{2}{c}{$\begin{array}{c}\text { Growth regulator treatment } \\
\text { experiment }\end{array}$} \\
\cline { 2 - 3 } Taxon & \% Callus & \% Shoots & & \%allus & \% Shoots \\
\hline$P$. virginiana & $96.5 \mathrm{a}^{z}$ & $36.8 \mathrm{a}$ & & $92.0 \mathrm{a}$ & $28.6 \mathrm{a}$ \\
$P$. maackii & $52.5 \mathrm{c}$ & $19.9 \mathrm{~b}$ & & $50.4 \mathrm{~b}$ & $11.5 \mathrm{~b}$ \\
$P$. serrula & $81.8 \mathrm{~b}$ & $10.0 \mathrm{~b}$ & & $92.5 \mathrm{a}$ & $21.7 \mathrm{a}$ \\
$P$. serrulata & $18.4 \mathrm{~d}$ & $0.0 \mathrm{c}$ & & $35.8 \mathrm{c}$ & $3.8 \mathrm{c}$ \\
$P$. sargentii & $66.9 \mathrm{bc}$ & $0.0 \mathrm{c}$ & & $45.4 \mathrm{bc}$ & $1.1 \mathrm{~cd}$ \\
$P$. yedoensis & $55.3 \mathrm{c}$ & $0.0 \mathrm{c}$ & & $24.0 \mathrm{~d}$ & $0.3 \mathrm{~d}$ \\
$P$. subhirtella & $73.3 \mathrm{bc}$ & $0.0 \mathrm{c}$ & & --- & -- \\
\hline
\end{tabular}

${ }^{\mathrm{z}}$ Mean separation within columns by LSD, $P \leq 0.05$. tween the planned comparison means of cotyvs. hypocotyls, whole cotyledons vs. half cotyledons, or notched vs. unnotched cotyonsignificant.

and seed source on regeneration. The percentage of cotyledons that produced callus did not treatments, but there was a significant differthan other taxa (Tables 1 and 2). Seed source effect and seed source by taxa interaction for callus formation were also significant. The o seed sources differed significantly in $P$. not shown). When taxa from the first seed source were compared, P. maackii, $P$. sargentii, and $P$. yedoensis all produced significantly more callus than $\operatorname{did} P$. serrulata. Data for the did not differ from $P$. serrulata, but that $P$. sargentii and $P$. yedoensis produced significantly less callus than did $P$. maackii and $P$. serrulata. From the remaining two replicates subhirtella, which was not included in average of $17.9 \%$ of the cotyledons formed callus and $<1 \%$ formed shoots. 
The percentage of cotyledons that produced shoots differed significantly among taxa and among growth regulator treatments, and interactions between taxon and treatment and between taxon and seed source were significant, as was as a three-way interaction among taxon, treatment, and seed source (Tables 1 and 2). Treatments 1 and 4 produced the most shoots (17\% and $16.8 \%$, respectively) across all taxa (Table 3). Means for seed source across growth regulator treatments differed significantly for $P$. maackii, $P$. serrula, and $P$. sargentii (Table 3 ).

The percentage of cotyledons with shoots differed significantly among the taxa over the growth regulator treatments (Tables 2 and 3$)$. In general, $P$. virginiana produced the most shoots followed by $P$. serrula, although these two taxa did not differ significantly. Only on a combination of $1.0 \mu \mathrm{M} 2,4-\mathrm{D}$ and 4.4 $\mu \mathrm{M}$ BA (Treatment 7) did $P$. serrula significantly outperform $P$. virginiana (Table 3 ). Prunus maackii generally produced fewer shoots than did $P$. virginiana and $P$. serrula, but more than $P$. serrulata, $P$. sargentii and $P$. yedoensis (Table 2). Only in treatment 9 (4.5 $\mu \mathrm{M} 2,4-\mathrm{D}+0.5 \mu \mathrm{M}$ BA, transferred to $0.3 \mu \mathrm{M}$ $\mathrm{NAA}+2.5 \mu \mathrm{M}$ BA and then to $0.5 \mu \mathrm{M} \mathrm{NAA}+$ $5 \mu \mathrm{M}$ BA) was there no significant difference among taxa, and none of the taxa did well on this combination of growth regulators (Table 3).

Callus formation was not significantly different in the planned comparisons among growth regulator treatments (Table 1). Prunus virginiana cotyledons formed significantly more shoots on growth regulator combinations with TDZ (Treatments 1-5) than on those without TDZ (Treatments 6-9) (Tables 1 and 3). This trend was also observed in $P$. maackii, although differences were not significant in this taxon (Table 3 ).

\section{Discussion}

Although there were some differences among embryo explants and growth regulator treatments in callus and shoot formation, these differences were generally nonsignificant within taxa, and the results were reasonably consistent between the two seed sources. However, there were significant differences between the taxa in their regeneration potential. Prunus virginiana, $P$. serrula, and $P$. maackii consistently produced callus and shoots in almost all of the treatments (Tables 2 and 3). Prunus serrulata, $P$. sargentii, $P$. subhirtella, and $P$. yedoensis all produced callus, but only a small percentage of the explants formed adventitious shoots (Tables 2 and 3 ). Although explants that formed callus did not necessarily produce shoots, only explants that formed callus also formed shoots. Prunus campanulata produced no callus, and therefore no shoots, regardless of treatment (results not shown). There were no visible signs of contamination inhibiting its response, although the presence of endogenous bacteria was not assessed. We were able to obtain only a single seed lot; thus it is not clear whether this lack of response could have been due to nonviability of the seeds, reaction to the disinfection, genetic, or developmental factors.

Some qualitative differences in the callus produced warrant discussion. First, among the embryo explants, although cotyledons did not differ from hypocotyls in the percentage with callus (Table 1), note that in all taxa (except $P$. campanulata), hypocotyls swelled to $\approx 10$ times the original size and were uniformly covered with soft, friable callus after 4 weeks on regeneration media. In some preliminary experiments, we compared hypocotyls with whole cotyledons, but in spite of callus formation on hypocotyls, shoot formation was no better than on cotyledons. Shoots formed only on hypocotyls of $P$. virginiana, $P$. maackii, and $P$. serrula. Hypocotyl slices were used by Mante et al. (1991) to successfully transform plum.

Qualitative differences among taxa were also observed when cotyledons were used as explants. Prunus maackii cotyledons generally swelled and became uniformly covered with callus, while $P$. virginiana cotyledons typically swelled and formed callus at the proximal and distal ends. Prunus serrula swelled, elongated, and curled, forming callus primarily at the proximal end; $P$. serrulata, $P$. sargentii, $P$. yedoensis, and $P$. subhirtella tended to produce patches of callus anywhere on the cotyledon. These observations were consistent within taxa, regardless of growth regulator combination used.

Prunus virginiana, $P$. maackii, and $P$. serrula cotyledons differed in the appearance and number of shoots formed. Of the three taxa, $P$. maackii shoots were healthiest and most vigorous, although there was some variation within this taxon. Prunus maackii cotyledons typically formed shoots after the fourth week, when they were moved from darkness to a 16-h photoperiod. By the twelfth week, $P$. maackii cotyledons with shoots had from five to 20 shoots that could be easily micropropagated. Prunus virginiana cotyledons began to form shoots by the second week, while still in the dark, and formed a large amount of callus and a number of shoots (five or more) by the end of the experiment, but the shoots were typically fasciated or hyperhydric in appear-

Table 3. Effects of growth regulators on percentage of cotyledons with adventitious shoots from six Prunus taxa after 12 weeks on MS medium.

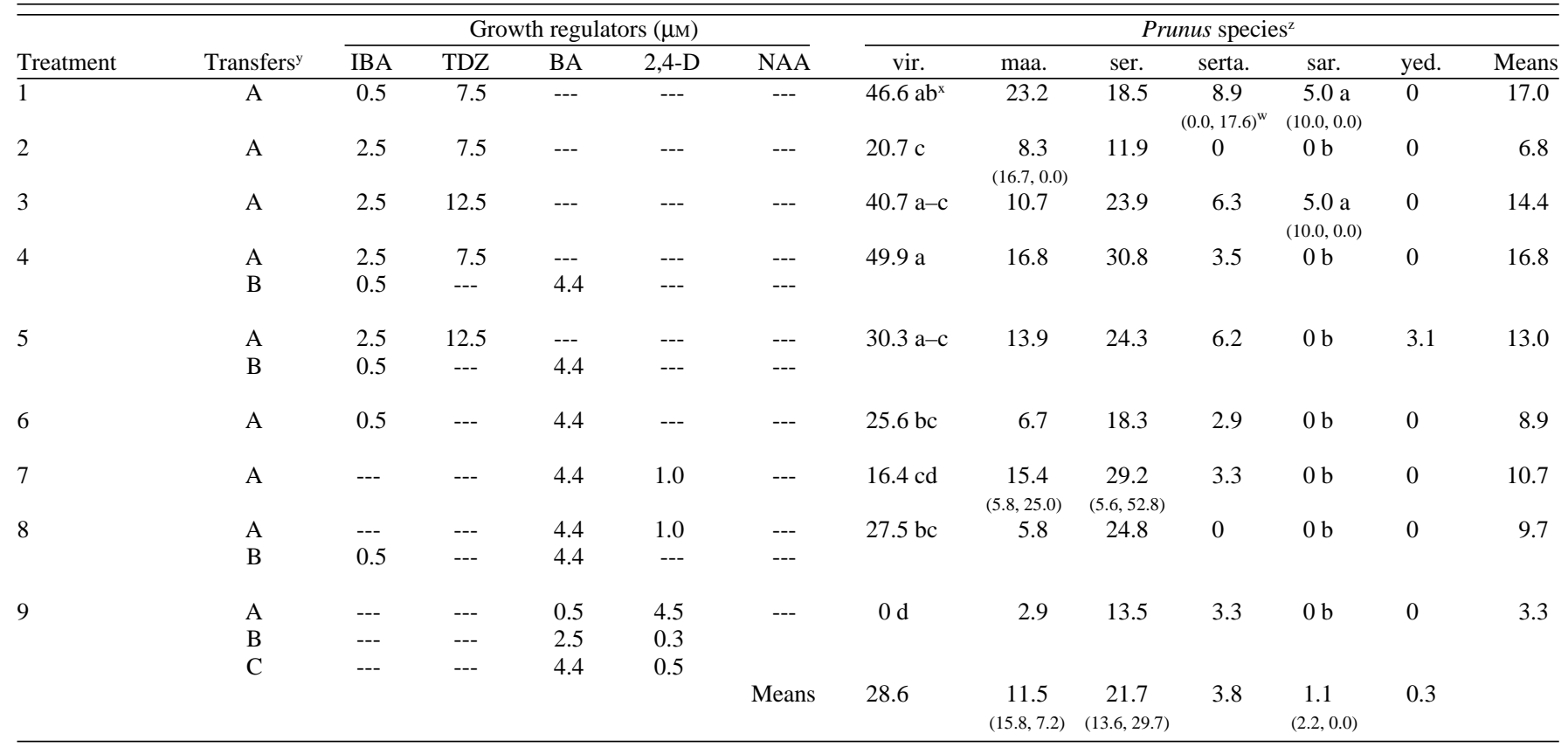

${ }^{2}$ Species abbreviations: vir. $=$ virginiana, maa. $=$ maackii, ser. $=$ serrula, serta.$=$ serrulata, sar. $=$ sargentii, yed. $=$ yedoensis.

${ }^{\mathrm{y}} \mathrm{A}$-first medium; B-second medium; $\mathrm{C}$-third medium

${ }^{x}$ Mean separation among growth regulator treatments within taxa where differences were significant. Differences among treatment means were nonsignificant in the other taxa.

wNumbers in parentheses are the mean percentage of cotyledons with shoots from the two different seed sources when those means were significantly different. 
ance and were difficult to transfer and maintain. Prunus serrula cotyledons often produced a single main shoot that dominated other smaller, less well-formed shoots, and cotyledons of this taxa also seemed to form roots sporadically on most of the growth regulator combinations.

We included growth regulator combinations with 2,4-D and/or NAA based on a report by Pieterse (1989). In that report, adventitious buds regenerated directly from immature cotyledons of 'Royal' apricot on the growth regulator combination that we used in treatments 7 and 8 in this experiment $\left(1.0 \mu_{\mathrm{M}} 2,4-\mathrm{D}+4.4\right.$ $\mu \mathrm{M}$ BA). A series of growth regulator combinations similar to those we tested in treatment $9(4.5 \mu \mathrm{M} 2,4-\mathrm{D}+0.44 \mu \mathrm{M}$ BA transferred to $0.53 \mu \mathrm{M}$ NAA $+2.2 \mu \mathrm{M}$ BA and then to $0.53 \mu \mathrm{M}$ $\mathrm{NAA}+4.4 \mu \mathrm{M} \mathrm{BA}$ ) were used for callus initiation, nodular callus formation, and regeneration from nodular callus. In our experiment, mature cotyledons from the ornamental cherry taxa generally did not respond any differently in percentage callus or shoot formation on these combinations, except that significantly fewer $P$. virginiana cotyledons produced shoots on the 2,4-D/NAA treatments than on combinations of IBA and TDZ or IBA and BA (Table 3). Callus that formed, particularly from $P$. maackii, on $4.5 \mu \mathrm{M} 2,4-\mathrm{D}+0.44$ $\mu \mathrm{MBA}$ in treatment 9 was sometimes lighter in color and glossier than callus in the other treatments. It appeared to be potentially embryogenic, but no embryogenic activity was observed histologically.

The most striking result of these experiments is the variability among the ornamental cherry taxa in regeneration from mature seeds, regardless of how the seeds were treated. Five of the taxa, $P$. serrulata, $P$. yedoensis, $P$. sargentii, $P$. subhirtella, and $P$. campanulata, were not amenable to shoot regeneration from mature cotyledons. That $P$. serrulata, $P$. yedoensis, $P$. sargentii, and $P$. campanulata are classified within one section of the subgenus Cerasus, while the other taxa represent separate sections or subgenera (Krussman, 1984 ) is of interest. Their inability to regenerate may be related to their lineage, as was demonstrated in Rubus by Grahametal. (1997). Planned comparisons among subgenera were not made. As with previous reports with peach and plum (Mante et al., 1989), immature cotyledons might be a better source for shoot regeneration in these Prunus taxa.

Differences in regeneration potential between seed lots within some taxa were not unexpected, considering that these open-pollinated seeds were harvested from trees in different states. Although each seed represents a unique genotype, and clearly some genotypes will regenerate more efficiently under our test parameters than others, we consider trends within a taxon to be of primary use and importance, since these data will allow us to focus our transformation efforts on taxa that regenerate well.

Based on the percentage of explants forming shoots, three of the ornamental cherry taxa studied here, $P$. maackii, $P$. virginiana, and $P$. serrula, are potential candidates for genetic engineering via Agrobacterium or particle bombardment. A transformation system from seed material is useful to genetically engineer Prunus germplasm, but is not effective for manipulating traits in specific cultivars. Regeneration from leaf material should be investigated in these and other taxa, since such a system would lead to direct transformation of cultivars, rather than the transformation of seedling tissue, as our cotyledon regeneration system potentially allows.

\section{Literature Cited}

Akaike, H. 1974. A new look at the statistical model identification. IEEE Transactions on Automatic Control, AC-19, 716-723.

Bassi, G. and F. Cossio. 1991. In vitro shoot regeneration of "Blufre" and "Susina di Dro" prune cultivars (Prunus domestica L.). Acta Hort. 289:81-82.

Birch, R.G. 1997. Plant transformation: Problems and strategies for practical application. Annu. Rev. Plant Physiol. Plant Mol. Biol. 48:297-326.

Capellades Queralt, M., M. Beralt, A. Vanderschaeghe, and P.C. Debergh. 1991. Ornamentals, p. 215-229. In: P.C. Debergh and R.H. Zimmerman (eds.). Micropropagation. Kluwer Academic Publishers, Dordrecht, The Netherlands.

da Camara Machado, A., M. Puschmann, H. Puhringer, R. Kremen, H. Katinger, and M. L. da Camara Machado. 1995. Somatic embryogenesis of Prunus subhirtella autumno rosa and regeneration of transgenic plants after Agrobacterium-mediated transformation. Plant Cell Rpt. 14:335-340.

Geneve, R.L., J.E. Preece, and S.A. Merkle. 1997. Biotechnology of ornamental plants, Biotechnology in Agriculture Series, No. 16. CAB Intl., Wallingford, Kent, U.K.

Graham, J., L. Iasi, and S. Millam. 1997. Genotypespecific regeneration from a number of Rubus cultivars. Plant Cell Tiss. Org. Cult. 48:167173.

Hammerschlag, F.A., G. Bauchan, and R. Scorza. 1985. Regeneration of peach plants from callus derived from immature embryos. Theor. Appl. Genet. 70:248-251.

Krussman, G. 1984. Manual of cultivated broadleaved trees and shrubs, vol. III, Pru-Z. Timber Press, Portland, Ore.

Littell, R.C., G.A. Milliken, W.W. Stroup, and R.D. Wolfinger. 1996. SAS® system for mixed models. SAS Inst., Cary, N.C.

Mante, S., P.H. Morgens, R. Scorza, J.M. Cordts, and A.M. Callahan. 1991. Agrobacterium-mediated transformation of plum (Prunus domestica L.) hypocotyl slices and regeneration of transgenic plants. Biotechnology 9:853-857.

Mante, S., R. Scorza, J.M. Cordts. 1989. Plant regeneration from cotyledons of Prunus persica, Prunus domestica, and Prunus cerasus. Plant Cell Tiss. Org. Cult. 19:1-11.

McCown, B.H. 1986. Woody ornamentals, shadetrees and conifers, p. 333-342. In: R.H Zimmerman, R.J. Griesbach, F.A. Hammerschlag, and R.H. Lawson (eds.). Tissue culture as a plant production system for horticultural crops. Martinus Nijhoff, Dordrecht, The Netherlands.

Mehra, A. and P.N. Mehra. 1974. Organogenesis and plantlet formation in vitro in almond. Bot. Gaz. 135:61-73.

Miguel, C.M., P. Druart, and M. M. Oliveira. 1996. Shoot regeneration from adventitious buds induced on juvenile and adult almond (Prunus dulcis Mill.) explants. In Vitro Cell. Dev. Biol.Plant 32:148-153.

Pieterse, R.E. 1989. Regeneration of plants from callus and embryos of 'Royal' apricot. Plant Cell Tissue Organ Cult. 19:175-179.

Pooler, M.R. and R. Scorza. 1995. Regeneration of peach (Prunus persica L. Batsch) rootstock cultivars from cotyledons of mature stored seed. HortScience 30:355-356.

Ravelonandro, M., R. Scorza, J.C. Bachelier, G. Labonne, L. Levy, V. Damsteegt, A.M.Callahan, and J. Dunez. 1997. Resistance of transgenic Prunus domestica to plum pox virus infection. Plant Dis. 81:1231-1235.

Read, P.E. and M.A. Hosier. 1986. Tissue culture propagation of ornamental crops: An overview, p. 283-285. In: R.H. Zimmerman, R.J. Griesbach, F.A. Hammerschlag, and R.H. Lawson (eds.). Tissue culture as a plant production system for horticultural crops. Martinus Nijhoff, Dordrecht, The Netherlands.

Robinson, K.E.P. and E. Firoozabady. 1993. Transformation of floriculture crops. Scientia Hort. 55:83-99.

SAS Institute. 1997. SAS/STAT® Software: Changes and enhancements through release 6.12 . SAS Inst., Cary, N.C.

Schuerman, P.L. and A.M. Dandekar. 1993. Transformation of temperate woody crops: Progress and potentials. Scientia Hort. 55:101-124.

Zuker, A., T. Tzfira, and A. Vainstein. 1998. Genetic engineering for cut-flower improvement. Biotech. Adv. 16:33-79. 